\title{
THE ROLE OF INDEPENDENT COMMISSIONERS IN MODERATING THE EFFECT OF FAMILY OWNERSHIP AND FOREIGN OWNERSHIP ON DIVIDEND POLICY
}

\author{
Mnune Tresna Dewi ${ }^{\star}$, Purbawangsa Ida Bagus Anom \\ Faculty of Economics and Business, University of Udayana, Bali, Indonesia \\ *E-mail: tresnadewim@gmail.com
}

\begin{abstract}
The purpose of this study is to obtain empirical evidence regarding the effect of family ownership and foreign ownership on dividend policy and to examine the role of independent commissioners in moderating the effect of family ownership and foreign ownership on dividend policy. The sampling technique used nonprobability sampling method with purposive sampling technique. The data used in this study is secondary data obtained from the financial statements of service companies listed on the Indonesia Stock Exchange (IDX) for three years, 2017 to 2019. The data analysis technique uses multiple linear regression and moderated regression analysis. The results of this study indicate that family ownership and foreign ownership have a positive and significant effect on dividend policy, independent commissioners do not moderate the effect of family ownership on dividend policy and independent commissioners weaken the influence of foreign ownership on dividend policy. The implications of the research findings are that it can enrich the research model and support other empirical studies related to the effect of family ownership and foreign ownership on dividend policy and the role of independent commissioners in moderating the effect of family ownership and foreign ownership on dividend policy.
\end{abstract}

\section{KEY WORDS}

Dividend policy, family ownership, foreign ownership, independent commissioner.

Dividend policy is a form of financial decision related to the rights of shareholders regarding whether the profits earned by the company will be distributed to shareholders or retained in the form of retained earnings to finance investments in the future (Sartono, 2010: 281). The value and timing of dividend payments are determined by the General Meeting of Shareholders (GMS). At the GMS, the majority of votes have control over the decisions that will be made by the company, including those related to dividend policy. Therefore, the company's ownership structure is important to determine the dividend policy taken by the company (Sutojo and Aldridge, 2008: 16).

Based on the results of a survey conducted by Price Waterhouse Coopers (PWC) more than 95 percent of companies in Indonesia are family businesses. There are two main things to know if a business is a family business or not. The first factor is that a business can be declared a family business if the ownership of the business is owned by the majority of the family. In a large company or one that has gone public, at least family members must own 25 percent of the ownership of the company and the family occupies the top position in the company. The second factor is the involvement of the family in the management of the company.

According to data from the Indonesian Central Securities Depository (KSEI) as of the end of August 2019, the total asset value of scripless shares reached IDR 3,735.5 trillion, equivalent to 51.21 percent of the total. Ownership of local investors reached $R p$ 1,822.57 trillion or 48.79 percent of the total asset value. Meanwhile, the value of assets owned by foreign investors reached Rp. 1,912.93 trillion or 51.21 percent of the total value of scripless shares in KSEI (www.cnbcindonesia.com, 2019). With the majority composition, movements by foreign investors have a significant impact on the stock market in Indonesia.

The implementation of Good Corporate Governance (GCG) is closely related to agency theory which emphasizes supervision and control. The supervisory system on the implementation of GCG is carried out by independent commissioners to ensure that 
management has acted in the interests of shareholders by accurately reporting all activities assigned to management and protecting the equality of controlling and minority shareholders (National Committee on Governance Policy, 2006).

This research was conducted on service sector companies listed on the IDX. According to a researcher from the Institute for Development of Economics and Finance (INDEF), Indonesia's economy has turned to the service sector. In addition, based on data from KSEI, companies in the service sector are the companies that distributed the most dividends for the 2016 to 2020 period (www.ksei.com, 2020). This shows that in the service sector there are many companies that can be used as attractive investment objects for investors who expect dividends as a result of their investments. The large number of companies that distribute dividends in the service sector also shows that the company has fulfilled the rights of shareholders through dividends. Based on the controversy over the influence and research gap regarding the relationship between family ownership and foreign ownership on dividend policy as well as indications of the moderating variable, namely the independent commissioner, it is interesting to re-examine and clarify the relationship between family ownership and foreign ownership on dividend policy with the independent commissioner as the moderating variable.

\section{LITERATURE REVIEW}

Companies tend to increase dividends if there is a high level of profitability in the future and reduce dividends if management believes that there are no cash flows that can support dividend payments. Changes in dividend payments contain information that allows investors to revise their predictions about the company's prospects and as a result, stock price adjustments occur when dividend changes are announced (Deegan, 2014: 105).

Agency relationship occurs between shareholders as principal and management as agent. Agency theory emphasizes the importance of shareholders as principals to hand over company management to professionals who better understand daily business. (Putri and Ulupui, 2017: 23). Conflicts between shareholders and management due to ownership with a type of scattered ownership structure are called agency conflicts of type I (Scott, 2015: 60). Conflicts caused by concentrated ownership are called type II agency conflicts.

Horne and Wachowicz (2012: 270) state that the main aspect of dividend policy is determining the right allocation of profits between dividend payments and the company's retained earnings. Dividend policy is related to the decision whether the profits earned by the company will be distributed to shareholders as a form of compensation for the investment of funds made to the company or held as a form of company investment in the future (Wiagustini, 2014: 8). Conflicts of interest that occur between shareholders and managers can be resolved through GCG as a mechanism used to control management. The GCG mechanism is a procedure and a clear relationship between the parties who make decisions and those who control or supervise the decisions taken. The GCG mechanism aims to create added value for all interested parties, so that there is no conflict between managers and shareholders which results in a reduction in agency costs.

Family ownership is ownership of individuals and ownership of private companies (above 5 percent) that are not public companies, state, or financial institutions. The family as the majority shareholder has a significant amount of funds invested in the company and they cannot sell shares to diversify their wealth or for consumption because the family still wants to have control over the company in the long term. Therefore, families can use the company's dividend policy to meet their income needs (Isakov and Weisskopf, 2015). This is in accordance with research conducted by Sener and Selcuk (2019), Subramaniam (2018), Michiels et al. (2017), and Deslandes et al. (2016) stated that family ownership has a positive and significant effect on dividend policy.

According to Law no. 25 of 2007 in Article 1 point 6 foreign ownership is an individual foreign citizen, foreign business entity, and foreign government investing in the territory of the Republic of Indonesia. Companies with foreign ownership use dividends as a tool to monitor management performance and control management to work as expected (Zyguła, 2017). In 
addition, foreign shareholders place dividends as attractive income when the company does not have investment opportunities that promise high returns and limited access to investment projects (Brigham and Houston, 2015: 215). This is in accordance with research conducted by Musallam and Lin (2019), Obaidat (2018), Mili et al. (2017), Balagobei and Thiruchchenthurnathan (2016), Kowerski and Wypych (2016), Mossadak et al. (2016), and Al-Najjar and Kilincarslan (2016) found that the higher the concentration level of foreign share ownership, the higher the dividend paid.

Independent commissioners are members of the board of commissioners who are not affiliated with the board of directors, other members of the board of commissioners and the controlling shareholder, and are free from business or other relationships that may affect their ability to act independently (National Committee on Governance, 2006). The existence of supervision from an independent commissioner in terms of dividend payments will later give a signal to the market that the company has good governance marked by the interests of minority shareholders being well protected and there is no desire to take over by the majority shareholder. This is in accordance with research conducted by Rajput and Jhunjhunwala (2019), Poniman et al. (2018), Tunay and Yüksel (2017) and Riaz et al. (2016). Based on the studies described above, the research hypotheses that can be made are:

- H1: Family ownership has a positive effect on dividend policy;

- H2: foreign ownership has a positive effect on dividend policy;

- H3: Independent commissioners strengthen the positive influence of family ownership on dividend policy;

- H4: Independent commissioners strengthen the positive influence of foreign ownership on dividend policy.

\section{METHODS OF RESEARCH}

This research was conducted on service sector companies listed on the Indonesia Stock Exchange for the 2017-2019 period by taking data through the official website www.idx.com. The population in this study is all companies in the service sector listed on the IDX for the 2017-2019 period. The population of this study is 314 service sector companies listed on the IDX during the 2017-2019 period. Samples were taken from the population based on a non-probability approach using a purposive sampling technique (Sugiyono, 2016:85). Based on the established criteria, of the 314 service sector companies listed on the IDX for the 2017-2019 period as a population, only 25 companies are suitable to be used as research samples. This study uses multiple linear regression data analysis techniques (multiple linear regression) to test $\mathrm{H} 1$ and $\mathrm{H} 2$ and Moderated Regression Analysis (MRA) to test $\mathrm{H} 3$ and $\mathrm{H} 4$.

\section{RESULTS AND DISCUSSION}

Multiple linear regression analysis was used to test $\mathrm{H} 1$ and $\mathrm{H} 2$, namely to determine the effect of the independent variables, namely family ownership (X1), foreign ownership (X2) on the dependent variable, namely dividend policy $(Y)$ in service sector companies listed on the Indonesia Stock Exchange. 2017-2019. The results of multiple linear regression in this study can be seen in table 1 .

Table 1 - Multiple Linear Regression Results

\begin{tabular}{|c|c|c|c|c|c|c|}
\hline \multirow{5}{*}{$\begin{array}{l}\text { Model } \\
1\end{array}$} & \multirow{5}{*}{$\begin{array}{l}\text { (Constant) } \\
\text { KK } \\
\text { KA }\end{array}$} & \multicolumn{2}{|c|}{ Unstandardized coefficients } & \multirow{3}{*}{$\begin{array}{l}\text { Standardized coefficients } \\
\text { Beta }\end{array}$} & \multirow{3}{*}{$\begin{array}{l}\mathrm{t} \\
0,261\end{array}$} & \multirow{5}{*}{$\begin{array}{l}\text { Sig. } \\
0.778 \\
0.023 \\
0.000\end{array}$} \\
\hline & & $\mathrm{B}$ & Std. Error & & & \\
\hline & & 2.789 & 9.862 & & & \\
\hline & & 0.344 & 0.149 & 0,261 & 0,462 & \\
\hline & & 0.611 & 0.149 & 0,462 & 0,261 & \\
\hline R Square & 0.197 & & & F Value & 8.832 & \\
\hline Adjusted R Square & 0.175 & & & Sig. & 0.000 & \\
\hline
\end{tabular}

Source: processed data, 2021. 
Based on the analysis of the data that has been shown in Table 1, it can be made a multiple linear regression equation as follows:

$$
Y=2.789+0.344 X_{1}+0.611 X_{2}
$$

The adjusted $R 2$ value in this study is 0.175 , which means that the independent variables in this study, namely family ownership and foreign ownership in the regression model, simultaneously affect the dependent variable, namely dividend policy by 17.5 percent, while 82.5 percent is explained by other factors outside the independent variables used in this study. The results of the F test in this study indicate that the Sig value is $0.000<0.05$; it can be concluded that simultaneously the independent variables, namely family ownership and foreign ownership, have an effect on the dependent variable, namely dividend policy.

The regression coefficient value of family ownership (KK) is 0.344 with a significance level of $0.023<0.05$. Partially it can be concluded that family ownership has a positive and significant effect on dividend policy, thus $\mathrm{H} 1$ is accepted. Meanwhile, the regression coefficient of foreign ownership (KA) is 0.611 with a significance level of $0.000<0.05$. Partially it can be concluded that foreign ownership has a positive and significant effect on dividend policy, thus $\mathrm{H} 2$ is accepted.

The MRA in this study is used to test $\mathrm{H} 3$ and $\mathrm{H} 4$, namely to test whether the independent commissioner variable affects the relationship of family ownership to dividend policy and the relationship of foreign ownership to dividend policy in service sector companies listed on the IDX for the 2017-2019 period. The results of the regression equation for MRA in this study can be seen in Table 2.

Table 2 - Regression Results with MRA

\begin{tabular}{|c|c|c|c|c|c|c|}
\hline \multirow{3}{*}{$\begin{array}{l}\text { Model } \\
1\end{array}$} & \multirow[b]{3}{*}{ (Constant) } & \multicolumn{2}{|c|}{ Unstandardized coefficients } & \multirow{2}{*}{$\begin{array}{l}\text { Standardized coefficients } \\
\text { Beta }\end{array}$} & \multirow{3}{*}{$\begin{array}{l}\mathrm{t} \\
0.100\end{array}$} & \multirow{3}{*}{$\begin{array}{l}\text { Sig. } \\
0.920\end{array}$} \\
\hline & & $B$ & Std. Error & & & \\
\hline & & 3.494 & 34.770 & & & \\
\hline & KK & 0.307 & 0.604 & 0.223 & 0.509 & 0.613 \\
\hline & $\mathrm{KA}$ & 1.828 & 0.566 & 1.383 & 3.229 & 0.002 \\
\hline & $\mathrm{KI}$ & 0.001 & 0.768 & 0.000 & 0.001 & 0.999 \\
\hline & $\mathrm{KK}^{*} \mathrm{KI}$ & 0.000 & 0.013 & 0.006 & 0.010 & 0.992 \\
\hline & $\mathrm{KA}^{*} \mathrm{KI}$ & -0.027 & 0.013 & -0.990 & -2.070 & 0.042 \\
\hline R Square & 0.311 & & & F Value & 6.219 & \\
\hline Adjusted R Square & 0.261 & & & Sig. & 0.000 & \\
\hline
\end{tabular}

Source: processed data, 2021.

Based on the analysis of the data that has been shown in Table 2, the following regression equation can be made:

$$
Y=3.494+0.307 X_{1}+1.828 X_{2}+0.001 Z_{1}+0.000 X_{1} Z_{1}-0.027 X_{2} Z_{1}
$$

The adjusted R2 value in this study is 0.261 , which means that the independent and moderating variables in this study, namely family ownership, foreign ownership and independent commissioners in the regression model simultaneously affect the dependent variable, namely dividend policy by 26.1 percent, while 73.9 percent is explained by other factors outside the independent variables used in this study. The results of the F test in this study showed a Sig value of $0.000<0.05$; it can be concluded that simultaneously independent and moderating variables, namely family ownership, foreign ownership and independent commissioners have an effect on the dependent variable, namely dividend policy.

The significance level of the independent commissioner $(\mathrm{KI})$ is $0.999>0.05$, which means that it is not significant. Meanwhile, the significance level of the interaction between family ownership and independent commissioners $\left(\mathrm{KK}^{*} \mathrm{KI}\right)$ is $0.992>0.05$, which means that it is not significant. Based on these results, it can be concluded that the independent commissioner is not a moderating variable that strengthens the influence of family ownership 
on dividend policy and belongs to the type of potential moderator (modulator homologiser), thus $\mathrm{H} 3$ is rejected. The significance level of the independent commissioner $(\mathrm{KI})$ is $0.999>$ 0.05 , which means that it is not significant. Meanwhile, the significance level of the interaction between foreign ownership and independent commissioners (KA ${ }^{*} \mathrm{KI}$ ) is 0.042 $<0.05$, which means it is significant. The coefficient of interaction variable between foreign ownership and independent commissioners is -0.027 . Based on these results, it can be concluded that the independent commissioner is a moderating variable that weakens the influence of foreign ownership on dividend policy and is classified as pure moderator, thus $\mathrm{H} 4$ is rejected.

Companies with family ownership often show that dividends bridge the gap in the agency relationship between managers and shareholders and with majority and minority shareholders. The results of this study support the agency theory which states that agency conflicts that occur can be overcome by placing the family as shareholders and management. Shareholders place dividends as a form of income certainty because current dividends are less risky than getting capital gains in the future and there is uncertainty about the company's cash flows in the future. The results of this study support the bird in the hand theory which states that cash on hand in the form of dividends is more valuable than capital gains. Therefore, families can use the company's dividend policy to meet their income needs. High dividend payouts in family companies also support the signaling theory which states that dividends in family companies provide a positive signal containing information that the company is able to align family and non-family interests. This will have an impact on increasing the company's reputation. Reputation is important in a family company because it allows an increase in capital in the future and will be able to attract shareholders to invest which will have an impact on increasing the value of the company. The results of this study are in accordance with the first hypothesis $(\mathrm{H} 1)$ and research from several previous researchers, namely Sener and Selcuk (2019), Madyan et al. (2019), Subramaniam (2018), Michiels et al. (2017), and Deslandes et al. (2016).

Companies with foreign ownership where the majority shareholder is far from the company makes dividends as a tool to monitor management performance and control management to work as expected so that the results of this study support agency theory. The results of this study also support the signaling theory where foreign shareholders place dividends as attractive income when the company does not have investment opportunities that promise high returns and limited access to investment projects. This decision will minimize the misuse of the company's free cash flow by management if profits are not distributed to shareholders when there are no promising investments. The distribution of profits to shareholders in the form of dividends will send a signal to the market that the company has implemented good governance where the company is able to allocate existing profits as dividends. The results of this study are in accordance with the second hypothesis $(\mathrm{H} 2)$ and research from several previous researchers, namely Musallam and Lin (2019), Obaidat (2018), Wuisan et al. (2018), Mili et al. (2017), Balagobei and Thiruchchenthurnathan (2016), Kowerski and Wypych (2016), Mossadak et al. (2016), and Al-Najjar and Kilincarslan (2016).

According to Law no. 40 Regarding Limited Liability Companies, the boards of commissioners, including independent commissioners, are not allowed to interfere in making operational decisions. Independent commissioners are limited to providing advice and input to the board of directors, which is dominated by families, regarding things that should be done in accordance with the company's strategy and GCG principles. This means that the results of this study support agency theory where independent commissioners play a role in protecting the rights of minority shareholders but do not play a role in decision making related to dividend policy. Matters relating to the amount of dividends paid are still determined by the GMS where the voting rights owned by shareholders depend on the number of shares owned. The policy regarding dividend payments is actually still dominated by the family as the party with the majority of shares. Meanwhile, the role of the independent commissioner is only to ensure and provide input regarding the rights of minority shareholders which are still fulfilled and in accordance with GCG principles. This rule also reaffirms that the independent 
commissioner's most important role is the welfare of shareholders through increasing the value of the company (share price) not from the distribution of dividends. Based on the Dividend Irrelevance Theory dividend distribution is not able to increase the value of the company. Therefore, independent commissioners have no effect on dividend policy. The results of this study are not in accordance with the third hypothesis $(\mathrm{H} 3)$ but the results of this study are in line with the research conducted by Ahmed et al. (2020), Hendra and Anam (2020), Sakr and Youssef (2017), Mangasih and Asandimitra (2017) and Chasanah and Hermanto (2016)

Companies with foreign ownership have a good governance system due to the addition of science, technology and skilled financial experts. With the role of independent commissioners and a good governance system, the company has a strong supervisory and governance system so that agency costs are very low. The results of this study support the substitution theory which states that companies that have a good governance system will reduce agency costs so that the need to pay dividends will also decrease. In companies with a good governance system, independent commissioners would prefer to reinvest the company's profits rather than distribute them in the form of dividends. The results of this study are not in accordance with the fourth hypothesis $(\mathrm{H} 4)$ but the results of this study are in line with research conducted by Juhmani (2020), Pahi and Yadav (2018) and Al-Kahmisi et al. (2018).

\section{CONCLUSION}

Family ownership has a positive and significant effect on dividend policy. These results indicate that companies with family ownership use dividends as a tool to minimize agency conflicts that occur both between management and shareholders (agency conflict type 1) and between majority shareholders and minority shareholders (agency conflict type 2) which are very vulnerable to occur in the family company. In addition, dividends are also a signal that the company is able to align the interests of the majority shareholders, namely families and minority shareholders

Foreign ownership has a positive and significant effect on dividend policy. The presence of foreign shareholders who are far from the company is not a barrier for companies to create a good governance system because foreign ownership will provide additional skills, knowledge, technology and skilled financial experts. This is indicated by the fulfillment of the rights of shareholders to the company's profits in the form of dividends so that the higher the foreign ownership in the company, the higher the dividends paid.

Independent commissioners do not moderate the effect of family ownership on dividend policy. The existence of independent commissioners cannot influence operational decision making in the company, especially related to dividend policy. As long as there is no fraud or violation of GCG principles in making this decision, the role of the independent commissioner will not affect the results of the GMS.

Independent commissioners weaken the influence of foreign ownership on dividend policy. The existence of independent commissioners in companies with foreign ownership makes the governance system strong so that agency conflicts are low. If the company has a good governance system, agency costs will decrease so that the need to pay dividends will also decrease.

This study has several limitations, namely first, the study used a limited sample size of service companies with a limited research period of only three years. Future research can consider the following, namely expanding the sample size and period to include more companies and years to complement and enrich empirical studies related to this research topic. Second, this study uses only two forms of ownership structure. Meanwhile, there are other forms of ownership structure such as institutional ownership, managerial ownership and government ownership as well as other fundamental factors such as profitability, leverage, liquidity, and risk that may have an influence on dividend policy. Future research is expected to increase the number of research variables or choose variables that can be used to determine the factors that influence dividend policy. 


\section{REFERENCES}

1. Agoes, S., \& Ardana, I. C. (2014). Etika Bisnis and Profesi. Jakarta: Salemba Empat.

2. Ahmed, S., Shah, Zu. A., \& Bhatti, A. A. (2020). Roles of Corporate Governance and Ownership Structure In Dividend Smoothing Behavior of Asian Firms. International Transaction Journal of Engineering, Management \& Applied Sciences \& Technologies, 11(13), 1-12.

3. Al-Kahmisi, S., Adel, T., \& Hassan, H. H. (2018). The Effects of Corporate Governance on Dividend Payout Policies In Malaysian Banks. International Journal of Advanced Research and Publications, 2(2), 29-37.

4. Al-Najjar, B., \& Kilincarslan, E. (2016). The Effect of Ownership Structure on Dividend Policy: Evidence From Turkey. Corporate Governance: The International Journal of Business in Society, 16(1), 135-161.

5. Balagobei, S., \& Thiruchchenthurnathan, T. (2016). Impact of Ownership Structure on Dividend Payout Policy: An Empirical Study on Listed Plantation Companies in Sri Lanka. Research Journal of Finance and Accounting, 7(14), 93-98.

6. Benjamin, S. J., Wasiuzzaman, S., Mokhtarinia, H., \& Rezaie Nejad, N. (2016). Family Ownership and Dividend Payout In Malaysia. International Journal of Managerial Finance, 12(3), 314-334.

7. Brigham, F. E., \& Houston, F. J. (2015). Fundamentals of Financial Management. South Western: Cengage Learning.

8. Chasanah, S. M., \& Hermanto, S. B. (2016). Pengaruh Corporate Governance, Cash Position, Profitabilitas and Hutang Terhadap Kebijakan Dividen. Jurnal IImu and Riset Akuntansi, 5(8), 1-22.

9. Deegan, C. (2014). Financial Accounting Theory. New South Wales: Mc. Graw-Hill.

10. Deslandes, M., Fortin, A., \& Landry, S. (2016). Payout Differences Between Family and Nonfamily Listed Firms: A Socioemotional Wealth Perspective. Journal of Family Business Management, 6(1), 46-63.

11. Governance, K. N. K. (2006). Pedoman Umum Good Corporate Governance Indonesia.

12. Hendra, \& Anam, H. (2020). Pengaruh Good Corporate Governance Terhadap Kebijakan Dividen Pada Perusahaan Nonkeuangan. Jurnal GeoEkonomi, 11(2), 2086-1117.

13. Horne, J. C., \& Wachowicz, J. M. (2012). Prinsip-prinsip Manajemen Keuangan. (Edisi Dua). Jakarta: Salemba Empat.

14. Isakov, D., \& Weisskopf, J. P. (2015). Pay-Out Policies In Founding Family Firms. Journal Of Corporate Finance, 33(1), 330-344.

15. Juhmani, O. I. (2020). Corporate Boards, Ownership Structure And Dividend Payout: Evidence From Bahrain. Journal Of Critical Reviews, 7(12), 37-43.

16. Kowerski, M., \& Wypych, M. (2016). Ownership Structure and Dividend Strategy of Public Companies. Evidence from Poland. Barometr Regionalny. Analizy i Prognozy, 14(4), 179-192.

17. Madyan, M., Meidiaswati, H., Sasikirono, N., \& Herlambang, M. H. (2019). Family Control, Institutional Ownership, and Kebijakan Dividen Perusahaan Manufaktur yang Terdaftar Di Bursa Efek Indonesia. Jurnal Reviu Akuntansi and Keuangan, 9(1), 97-106.

18. Mangasih, G. V., \& Asandimitra, N. (2017). Pengaruh Insider Ownership, Institutional Ownership, Dispersion of Ownership, Collateralizable Assets, and Board Independence Terhadap Kebijakan Dividen Pada Sektor Finance Periode 2011-2015. Jurnal IImu Manajemen (JIM), 5(3), 1-8.

19. Michiels, A., Uhlaner, L., \& Dekker, J. (2017). The Effect of Family Business Professionalization on Dividend Payout. Journal Of Small Business and Enterprise Development, 24(4), 971-990.

20. Mili, M., Sahut, J. M., \& Teulon, F. (2017). Do Corporate Governance and Ownership Structure Impact Dividend Policy In Emerging Market During Financial Crisis?. Journal of Applied Accounting Research, 18(3), 274-297.

21. Mossadak, A., Fontaine, R., \& Khemakhem, H. (2016). The Relationship between Ownership Structure and Dividend Policy in an Emerging Market: A Moroccan Study. 
Universal Journal of Accounting and Finance, 4(2), 89-95.

22. Musallam, S. R., \& Lin, C. C. P. (2019). AN Ownership Structures and Dividend Policy: Evidence From Listed Plantation Companies In Malaysia. Management and Accounting Review (MAR), 18(2), 21-45.

23. Obaidat, A. N. (2018). Ownership Structure and Dividends Policy: Emerging Market Evidence. International Business Research, 11(6), 65-72.

24. Pahi, D., \& Yadav, I. S. (2018). Role of Corporate Governance in Determining Dividend Policy: Panel Evidence from India. International Journal of Trade, Economics and Finance, 9(3), 111-115.

25. Poniman, T, S., \& Ghofar, A. (2018). Pengaruh Kepemilikan Keluarga Terhadap Kebijakan Dividen Dengan Board Of Independence Sebagai Variabel Moderasi. Jurnal IImiah Manajemen, 8(3), 614-627.

26. Rajput, M., \& Jhunjhunwala, S. (2019). Corporate Governance and Payout Policy: Evidence From India. Corporate Governance: The International Journal of Business in Society, 19(5), 1117-1132.

27. Riaz, S., Liu, Y., \& Ahmad, M. I. (2016). Dividend Policy and Corporate Governance Perspective. Accounting and Finance Research, 5(3), 77-86.

28. Sakr, A., \& Youssef, N. (2017). The Effect of Corporate Governance on Bank's Dividend Policy: Evidence from JordanThe Effect of Corporate Governance on Mutual Fund Dividend Policy: Evidence from Egypt. Research Journal of Finance and Accounting, 8(4), 122-135.

29. Sartono, A. (2010). Manajemen Keuangan Teori and Aplikasi (Edisi Empa). Yogyakarta: BPFE.

30. Scott, Wi. (2015). Financial Accounting Theory (Seven Edit). Toronto: Pearson Prentice Hall.

31. Sener, P., \& Selcuk, E. A. (2019). Family Involvement, Corporate Governance and Dividends In Turkey. Managerial Finance, 45(5), 602-621.

32. Subramaniam, V. (2018). Family Ownership and Dividend Policy: Empirical Evidence from. International Journal of Business and Management, 13(5), 112-126.

33. Sugiyono. (2016). Metode Penelitian Bisnis (Pendekatan Kuantitatif, Kualitatif, and R\&D). Bandung: Alfabeta.

34. Sutojo, S., \& Aldridge, E. J. (2008). Good Corporate Governance (Tata Kelola Perusahaan yang Sehat). Jakarta: PT Damar Mulia Pustaka.

35. Tunay, K. B., \& Yüksel, S. (2017). The Relationship Between Corporate Governance and Foreign Ownership of The Banks In Developing Countries. Contaduría y Administración, 62(5), 1627-1642.

36. Wiagustini, N. L. P. (2014). Dasar-Dasar Manajemen Keuangan. Denpasar: Udayana University Press.

37. Wuisan, F., Randa, F., \& Lukman. (2018). Pengaruh Struktur Kepemilikan Terhadap Kebijakan Dividen Perusahaan. SiMAk, 16(2), 119-141.

38. Zyguła, A. (2017). Impact of Foreign Ownership on Dividend Policy In Poland. E-Finanse, 13(4), 76-88.

39. www.cnbcindonesia.com. 2019.

40. www.finance.detik.com. 2019.

41. www.ksei.co.id. 2020. 